Laboratory and the Swedish Water and Air Pollution Research Laboratory, the effects so far have been relatively mild in the free water (the pelagic zone) but severe along the coast (the littoral zone). Because the accident happened in autumn, the water was cold and life processes were few and slow. This reduced the effects on both marine and bird life: less than 100 birds so far seem to have been killed. Preliminary estimates show that, within four days of the grounding, the mortality of the zoo-plankton within $400 \mathrm{~m}$ of the tanker had significantly increased, and about $35 \%$ of the zooplankton had either been touched by or ingested oil. What was dramatic, however, was the effect on the littoral zone's bladder wrack community. It was found to be almost completely deserted after the spill. Small crustaceans and molluscs either died or left the area. Laboratory studies have also indicated sublethal effects on mussels and snails.

Dr Olle Linden, who is leading the Swedish investigations, points out that the dilution factor is very important in determining the amount of damage done to marine life by oil spills. Severe ecological disasters are more likely to occur in shallow, enclosed coastal water than in the open sea, where the oil generally disperses quickly. The oil spilled from the 'Tsesis' was pinned by winds against the shore. In the end, it was the geography that made the difference.

Wendy Barnaby

\section{Correction}

The Food and Agriculture Organisation's (FAO) budget for the biennium 1978-79 will be $\$ 211,350,000$ not $\$ 237,377,000$ as indicated on page 553 of last week's issue.

\title{
More natural gas for Pakistan
}

PAKISTAN is the only country in the East that seems likely to cushion the energy crisis by exploiting its natural gas reserves. This has become possible because of two major discoveries of gas reserves within a matter of 12 months. According to Dr Shahzad Sadiq, Chairman of the Oil \& Gas Development Corporation (OGDC), Pakistan is now in a position to export gas in liquid form or, as a gas, through overland pipelines. The western part of India is extremely gas-hungry and the possibility of piping gas to those regions is now being actively considered.

When last December a big natural gas reserve was discovered at Dhodak, in north Pakistan, the condensate oil in the reserve stole the limelight. The then Prime Minister, Mr Zulfiqar Ali Bhutto, chose to dramatise it by bringing a bottle full of oil to the floor of the National Assembly (The Parliament), and waving it within inches of the face of the Leader of the Opposition. Pakistan, which watched the display on TV, was thrilled. Oil had been struck!

However, the Dhodak find is essentially a natural gas reserve with some 5 million million $\mathrm{ft}^{3}$ of gas. And with yet another big gas discovery only last month and again in the north (at Pirkoh in Baluchistan) the focus is now on natural gas exploitation. The Pirkoh gas reserves are estimated to match those of Dhodak.

The Chief Martial Law Administrator General Mohammad Zia-ulhaq, who at present heads the government, visited Pirkoh earlier this month to inaugurate the gas-field and formally underline the importance of the new find in the overall economy of the country. Pakistan suffers balanceof-payments difficulties which are largely due to heavy imports of oil. At Pirkoh, the OGDC Chairman told General Zia-ul-haq that an investment of $\$ 250$ million in the development of newly discovered oil and gas fields could give a return of $\$ 230$ million annually. This can be earned in oil import substitution and in export of gas and surplus petroleum products.

The gas fields at Pirkoh and Dhodak are not the largest in Pakistan. The biggest one is isolated at Sui in Baluchistan and has an estimated reserve of 10 million million $\mathrm{ft}^{3}$. It has been exploited for the last two decades. Pirkoh and Dhodak are graded next to Sui in reserve contents. The fourth largest gas field, at Mari in upper Sind, has also been exploited for some time; its estimated reserves are some 4 million million $\mathrm{ft}^{3}$. Total gas reserves in Pakistan are now estimated to reach 30 million million $\mathrm{ft}^{3}$.

The most significant impact of natural gas in Pakistan has been on agriculture. The four big fertiliser factories already in production (largely producing urea, also some ammonium nitrate and ammonium sulphate) entirely depend on the natural gas for the power and feedstock requirements. In addition, four more big fertiliser projects, based on natural gas, are under way. The green revolution that has almost doubled the average yield of wheat, the staple grain, and rice through the introduction of dwarf varieties within the last decade calls for plenty of fertilisers as its most vital input.

As a result of the two natural gas discoveries it should be feasible to set up more fertiliser and cement plants, apart from proposed exports to ease the balance of payment position.

Azim Kidwai

\section{UK Agricultural research is blooming}

In contrast to the gloomy future foreseen for British science by many of its funding agencies, the UK Agricultural Research Council's (ARC) latest annual report for 1976-77, published last week, is almost cheerful. It reports a small growth for the Council's share of the DES Science Budget for 1976-77 and a period of stability in the Council's dealings with the Ministry of Agriculture, Fisheries and Food (MAFF) and the Department of Agriculture and Fisheries for Scotland, the Council's main customers under the Rothschild customer/contractor principle.

The ARC's increased share of the Science Vote over the past two years (its grant for $1977-78$ was $1.8 \%$ up in real terms on that for 1976-77), is attributed to a growing appreciation of the need for fundamental research in agricultural and related sciences by the Advisory Board for the Research Councils (ABRC). In particular, the ARC feels that it received sympathetic consideration when the ABRC allocated the extra money set aside for the research councils after the mini budget at the beginning of last month. Of the $£ 4$ million to be added to next year's Science Vote, the ARC will get $£ 300,000$. And of the $£ 4$ million to be spent on new capital work next year it will get $£ 800,000$.

Sir William Henderson, ARC Chairman, attributes part of the Council's success in winning the
ABRC's sympathies to the work of the Priorities Working Party set up in June 1976 to select areas of basic agricultural research which could be most suitably funded from the DES Science Budget. Under the heading 'plants and soils' it chose crop variability, soil/root relationships and crop bioenergetics as priority topics for research. It has yet to select priorities in 'animals' and 'food' subjects. In line with the choice of priority topics, however, the $£ 300,000$ bonus is to be spent on setting up a programme of genetic manipulation in plants in several institutes.

The $£ 800,000$ which has been set aside for construction will most probably be spent on the improvement and the extension of existing institutes.

Judy Redfearn 